\title{
S-GENE ACTION AND THE SIGNIFICANCE OF CHARACTERS IN THE HETEROSTYLOUS SYNDROME
}

\author{
RIVKA DULBERGER \\ Department of Botany, Tel-Aviv University, Israel
}

Received 4.vi.75

\begin{abstract}
SumMary
Heteromorphic characters of stigmas and pollen grains participate in the physiological mechanism of incompatibility. This points to incompatibility as a major factor in the evolutionary moulding of pollen and stigmas. A first reconstruction of $S$-gene action shows that it controls normal growth and differentiation of floral parts. The $S$ gene operates through a stepwise progression of events. The independently mutable subunits of the $S$ gene revealed by breakdowns of the heterostylous syndrome control stages in the chain of activities of the gene. Inception of pollen size heteromorphism during early meiosis indicates that sporophytic incompatibility factors may be derived not only from the tapetum, but from the pollen mother cells as well. It is suggested that the differential growth of styles and stamens in the morphs mediates the production of chemical recognition specificities and that metabolism related to wall extension plays an important role in incompatibility. The physiological basis of differential growth control in the morphs and the significance of pollen size heteromorphism are discussed.
\end{abstract}

\section{INTRODUGTION}

IN heterostylous plants, physiological incompatibility is genetically linked with morphological differences between pistils and stamens of the morphs. The significance of this association has been unclear. Darwin's suggestion (1877), which has been widely accepted, was that the complementary placing of stigmas and anthers in the foral morphs is a mechanical device for promoting insect-mediated pollinations between the morphs, which is reinforced by a distinct physiological mechanism of illegitimacy. Alternatively, Mather and De Winton (1941) suggested that the real significance of the morphological differences shown by pistils and stamens lies in the physiological differences which follow from them, and that the two mechanisms must be developmentally connected.

In all heterostylous plants in which incompatibility has been demonstrated, it is associated with heteromorphic characters of pollen grains, and in most cases of stigmatic papillae as well (Vuilleumier, 1967; Dulberger, 1974). The general consensus of opinion has been that these "secondary heteromorphic characters" have no direct significance for the physiology of incompatibility.

Recent findings indicate that heteromorphic characters of stigmatic papillae and pollen grains are involved in the physiology of incompatibility. 
The conclusions reached thereby and presented in this paper make coherent a substantial body of facts whose significance and relationships have until now been obscure. They also make $S$-gene action and the phenomenon of hererostyly more intelligible and throw light on more general problems as well.

\section{STIGMA AND POLLEN HeTEROMORPHisM}

In the Plumbaginaceae, structural dimorphism of the papilla wall, in association with dimorphism of papilla shape or size and dimorphism of the exine structure, apparently control incompatibility at the stages of pollen adherence and germination (Dulberger, 1975). More direct evidence for the role of dimorphism in incompatibility is provided by distylous Linum species, in which differences in size, structure and constituents of papillae and in the exine sculpture of the morphs have been reported (Heitz et al., 1971; Dulberger, 1974). Following the discovery of proteins on stigma cells (Mattson, Knox, Heslop-Harrison and Heslop-Harrison, 1974), Linum stigmas were stained with Coomassie brilliant blue. This revealed a differing stainability of the papilla wall, with Coomassie blue staining materials present in the thrum morph and absent in the pin morph, as in L. grandiflorum. The stigma dimorphism participates in the control of incompatibility. Affixation and germination of pollen grains and normal development of pollen tubes occur only in intermorph pollinations. In thrum $\times$ thrum pollinations, the pollen grains germinate, but the tubes are inhibited within the stigma (Darwin, 1877; Lewis, 1943). In pin $\times$ pin pollinations, the pollen grains usually fail to adhere. On rubbed or scraped stigmas, however, the grains do adhere and germinate, but the tubes are inhibited within the stigma. The adherence and germination of pollen from both morphs on thrum stigmas may be explained by the presence of exudate on papilla of this morph, and the inhibition of pin pollen on pin stigmas by its absence on such stigmas. However, the adherence and germination of thrum pollen on pin stigmas indicate that the surface of the pollen grain also participates in the recognition. In addition to chemical differences between the two pollen types (Lewis, 1943), it is possible that the mechanical effect of differing distribution and length of the exine processes, as observed with scanning microscopy, also play a role in recognition. It may be predicted that, at least in cases where the inhibition of pollen occurs on the stigma, pollen dimorphism will be found to be complemented by differences in structure or exudate of the stigma surface.

The most common pollen heteromorphism is one of size (Vuilleumier, 1966; Dulberger, 1974). It is interesting that suggestive indications regarding the role of pollen size dimorphism in incompatibility have been overlooked. Thus genetical studies on homostylous plants led Ernst (1933) to the conclusion that "legitimacy" depends exclusively on the relation between pollen size and style length. Legitimate are pollinations of long styles by large pollen and of short styles by small pollen, whether the pollen is produced by a different individual or by the same individual, in anthers at equivalent or differing levels from that of the stigma. Secondly, as early suggested (Darwin, 1877) correlation between pollen size and the length of the style through which the tubes must grow in a legitimate pollination has been demonstrated by Lewis (1942) and Lewis and Rao (1971), who also 
brought up a new correlate-the tube's rate of growth. I shall return later to the significance of pollen size heteromorphism. For the moment it should be pointed out that size dimorphism may be associated with differences in shape, exine patterning and number of apertures. Relevant instances have been reviewed by Köhler (1973). Furthermore, differences in pollen size may be associated with chemical specificities, such as the presence vs absence or scarcity of starch, or differing pigmentation (Dulberger, 1974).

The heteromorphism of pollen size, exine patterning, shape and number of apertures under heterostyly points to incompatibility as a major factor in the evolutionary moulding of pollen grains. A relation between incompatibility and the differentiation of the pollen wall has been noted by Köhler (1973). However, Köhler made no mention of the functional significance of such a relation. Recent work has revealed that the inapertural part of the exine is the site for deposition of sporophytic incompatibility substances derived from the tapetum (Dickinson and Lewis, 1973; Heslop-Harrison, Heslop-Harrison, Knox and Howlett, 1973; Howlett, Knox and HeslopHarrison, 1973). It has been suggested that dimorphic patterning of the exine might play a role by means of a differing distribution of incompatibility substances and might thereby participate in the mutual recognition between pollen and stigmas (Dulberger, 1975). Variation in the number of apertures within the confines of a heterostylous species suggests that this character may be important for recognition not only in gametophytic but also in sporophytic incompatibility. Intra-specific variation of pollen characters in heterostyly, as determined by incompatibility, adds a clue to the understanding of the evolution of pollen morphology in angiosperms, both in general and in specific cases of enigmatic intrageneric pollen variability.

\section{The efficiency of heterostyly as a meghanical device}

In the last decade, the efficiency of the complementary placing of stigmas and anthers for promotion of intermorph pollen flow and prevention of pollen wastage in incompatible intramorph pollinations has been investigated. However, the efficiency has been found to be considerably below theoretical expectations which follow from a Darwinian view (Ornduff, 1971). As shown by analyses of pollen loads found on stigmas, intermorph pollinations may be promoted by heterostyly, but may also occur no more frequently than in a random system of pollen distribution, or may even be restricted by heterostyly. Large-scale intramorph pollinations are not prevented and may even be more abundant than intermorph pollinations (Levin, 1968; Mulcahy and Caporello, 1970; Ornduff, 1970, 1971; Ganders, 1974).

The two-level seesaw in which anthers and stigmas interchange positions may have a positive selective value in the regulation of intermorph pollen distribution. The magnitude of this value, however, also depends on additional factors. The importance of an adequate relation between the size of a tubular corolla and the size of the pollinator for promotion of intermorph pollinations and avoidance of pollen wastage has been pointed out by Baker (1964). Significantly perhaps, Rubiaceae is the family which contains by far the largest number of heterostylous genera. Availability of nectar is a condition for more efficient pollen distribution. Even then, if combined with the positioning and activities of pollen-gathering insects, a rigorously proportional and economical pollen distribution between the morphs can 
hardly be expected. By supplying the needs of pollinators, excess pollen production and wastage are still adaptive in many flowers.

Therefore, the question is still open: why is heterostyly associated with di-allelic incompatibility, and why does it persist even in flowers whose morphs do not conform to ideal shape and pollen distribution requirements? The traditionally accepted view that differences in the length of styles and height of anthers and the nebulous physiology of incompatibility, although genetically linked, are two functionally independent mechanisms, has until now eclipsed an alternative explanation-that the length differences are in fact fundamental to the physiological mechanism.

\section{S-GENE ACTION}

In order to understand the inner dynamics of heterostyly, the times, sites and mode of action of the $S$ gene must be considered. For sporophytic incompatibility it has been postulated that $S$-gene action occurs during early meiosis in the anthers, or even earlier in the anther primordium (Lewis, 1954; Pandey, 1960), particularly in heteromorphic plants (Pandey, 1970). On the other hand, a later, tapetal action has been suggested (Heslop-Harrison, 1968) and demonstrated (Dickinson and Lewis, 1973; Heslop-Harrison, Knox and Heslop-Harrison, 1974). The time sequences and synchronies for a particular species cannot immediately be described. Fragmentary information none the less provides a basis for a first reconstruction of $S$-gene action.

Pollen size dimorphism in heterostylous plants, e.g. Primula, is already recognisable during early meiotic prophase (Dahlgren, 1916). An earlier evocation of the $S$ gene is indirectly indicated by a correlation which must exist between differences in pollen size and proportional differences between anther size and/or the number of grains in the morphs. Since in Primula the anthers are equal-sized (Darwin, 1877), the number of grains in the morphs must differ, as demonstrated by Ornduff (1971) for Fepsonia. A differing size of pollen grains thus points to a distinction in the number of mitoses in the morphs, at least in the sporogenous tissue, and indicates a higher rate of divisions in anthers of the pin morph than in the thrum morph. Dimorphisms of exine patterning, pollen shape, number of apertures and pigmentation appear during the tetrad and free-spore periods (HeslopHarrison, 1971). Tapetal incompatibility substances are transferred and deposited into the exine until maturation of the grains is complete (Dickinson and Lewis, 1973; Heslop-Harrison, Heslop-Harrison, Knox and Howlett, 1973; Heslop-Harrison, Knox and Heslop-Harrison, 1974). However, developments leading to the synthesis of such substances and particularly a differing pigmentation of anther walls as in Lythrum (Darwin, 1877) point to a more precocious differential commitment of the anthers in the morphs, not later than at the archesporium stage. A chemical specificity, such as starch in pollen of Lythrum and Oxalis, becomes stainable only a few days before anthesis. A differing number of ovules in the morphs (Bräm, 1943) is not dissociable from other activities of the $S$ gene, and also points to its early manifestation in the floral apex. A distinction between the morphs may also occur in the ovules, as hinted by differences in the weight and size of seeds (Darwin, 1877).

In young buds the length of styles and the anther levels are equal in the 
morphs. This stage is characterised by cell divisions and growth. Subsequently, the differences in height begin to appear. They are brought about almost exclusively by elongation of pre-existing cells in the long style and long stamen filaments, until they reach their final heights at anthesis (Ernst, 1932; Schaeppi, 1935; Bräm, 1943). Perhaps the last to appear in the $S$-gene repertoire, before the confrontation of the female and male partners, are the stigma specificities, as shown by the ontogeny of structure and exudate dimorphism of papillae in Linum (Dulberger, 1974).

From the foregoing some important points emerge. (1) The $S$ gene is part of the genetical control of normal growth and differentiation of flowers. (2) The $S$ gene operates through a stepwise progression of stages, all leading to the final incompatibility specificities of the male and female parts. (3) The independently mutable subunits of the $S$ gene revealed in various instances of changes in the heterostylous complex (Lewis, 1954; Dowrick, 1956) control stages in the chain of activities of the gene.

Inception of pollen size heteromorphism in the meiocytes strongly suggests that incompatibility factors of the pollen may originate in these cells or in the sporogenous tissue. It is conceivable that in heteromorphic plants, which have bi- or trinucleate grains (Brewbaker, 1957; Pandey, 1960), and possibly in homomorphic plants with trinucleate grains and sporophytic incompatibility as well, recognition factors of the pollen may differ in their origin and site. They may originate from the tapetum and be deposited into the exine, as already demonstrated. But the possibility is still open that precursors of sporophytic incompatibility factors might also be derived from the sporogenous tissue or from the pollen mother cells, as suggested by Pandey (1970), undergo changes during the meiotic cycle and subsequent growth at the free-spore period, and be incorporated into the intine, or, as indicated by starch specificity, be included in the cytoplasm. A combined action of incompatibility factors from differing sites in the pollen, and operating at different stages of pollen tube development, is also conceivable. The ultrastructural basis for persistence of incompatibility determinants during the de-differentiation of cytoplasmic organelles in the meiotic prophase and biochemical details of their conversion raise questions similar to those pointed out by Heslop-Harrison (1971) for the determination of exine patterning. Pollen size heteromorphism none the less suggests that wall extension plays an important role in their incorporation into the intine.

To recapitulate, where di-allelic incompatibility operates with heterostyly, not only pollen and stigma heteromorphism but also the lengths of the style and stamens are involved in controlling the physiological mechanism.

In Primula, Lewis (1942) explained the strong inhibition in thrum $\times$ thrum pollinations in contrast to the weak or nonexistent inhibition in pin $\times$ pin pollinations by the adjustment of pollen size to style length in a compatible combination. Since the larger thrum pollen is adapted for growing down a long style, it must be twice as strongly inhibited in the short style, which is only half as long, in order to assure the same security against self-fertilisation. Remarkably, similar conclusions are reached when data for distant Fagopyrum (Schoch-Bodmer, 1934) and Lythrum (Esser, 1953; Dulberger, 1970) are analysed. It seems as if a common principle is involved in the action of heterostyly, in spite of its polyphyletic origin.

What is the underlying mechanism of differential inhibition in the pistil types? It seems to me that the answer lies in the processes set in train by 
repression of growth of the short style and stamens, and by the induction of growth through cell elongation in the long style and stamens. It is suggested that the differential growth mediates the production of the chemical specificities. Recent progress in the biochemistry and metabolism of the cell wall revealed that the process of wall extension involves structural and metabolic changes, including changes in proteins (Lamport, 1970; Cleland, 1971). Qualitative differences between pistils and pollen of the morphs are plausible. However, the possibility of an all or nothing effect, or as Jost (1907) has suggested, of a quantitative difference in the same incompatibility factor, cannot be rejected.

Why, then, is di-allelic incompatibility associated with differences in style and stamen lengths even in cases where inhibition of pollen occurs on the stigma, and no differential interactions between pollen tubes and stylar tissues are involved in the incompatibility reaction? It would seem that in these cases, too, the production of the incompatibility specificities is preconditioned by metabolic changes related to differential growth. The fact that in the Staticeae heteromorphic incompatibility also occurs without distyly (Baker, 1966) does not disprove the role of the growth inducing/ repressing process in incompatibility; rather it may show that in these plants, the type of growth-expressed inter alia in the unique shape dimorphism of papillae-and the metabolic track leading to the final specificities, are different from those in other plants. Consequently, the nature of the recognition must be different.

The view that processes related to cell growth are involved in the production of incompatibility specificities is supported by the self-compatibility of homostylous and subheterostylous flowers, as well as in small endseason flowers (Dowrick, 1956; Ubisch, 1925) and buds (Esser, 1953). Analogous instances to the latter phenomena, but in homomorphic incompatibility, lead to the same conclusion.

In Plumbaginaceae and Linum, the structural differences between stigmatic papillae of the morphs and the behaviour of pollen grains on the stigmas show that the papilla wall is a site for recognition factors. It is reasonable to suppose that such factors are produced through differential extension of the papilla wall in the morphs, as is also expressed in papilla size or shape dimorphism. Since the styles, too, differ in the degree of extension of the cell wall, which is related to a differing metabolism, it is reasonable to conclude that in cases of inhibition within the pistil as well, the recognition site is the wall of cells in the transmitting tissue. In the pollen, the association of heteromorphic characters is significant. The larger grains may have more apertures as well as a coarse reticulation of the exine, in contrast to a finer one in the small grains. The incidence of these characters in the morphs can be interpreted as an adjustment of recognition sites in the pollen to the size of papillae and cells in the transmitting tissue and their recognition sites. Observations on aperture size and the thickness of the pollen tubes in Fagopyrum (Schoch-Bodmer, 1934) lead to the conclusion that pollen size, together with the number of apertures, may regulate the thickness of the tube.

Work on the physiology of sex expression in plants provides a basis for understanding the control of growth relations of pistils and stamens in heterostyly. In Silene pendula, auxin controls an inverse correlation in the relative growth of gynoecium and androecium (Heslop-Harrison and Heslop- 
Harrison, 1958). The auxin concentration promoting maximal stamen growth is lower than that promoting maximal pistil growth. Moreover, Heslop-Harrison (1957) suggested that in dioecy there is segregation of genetical factors controlling the level of auxin accumulation at the apex, or the separation of optimal concentration peaks for stamen and carpel production, or both. An explanation of this kind is adaptable to the factors controlling the dual condition of pistil and stamen growth in distyly, as well as for tristyly, which will be treated elsewhere. Control of a similar nature is also suggested by instances in which dioecy is a condition derived from distyly (Ornduff, 1966).

It is probable that the sporophytic release of genetical information by the $S$ gene marks the end of a chain of nucleo-cytoplasmic communication expressed in the morphs through distinguishing properties at the vegetative stage. An illuminating, though overlooked example is found in Linum (Laibach, 1930), in which both the seeds of pin plants and the plants themselves develop more slowly than thrum plants. More significantly, as if illustrating a missing link in the controlling chain, pin plants start flowering later than thrums, even if they have germinated on the same day. Heterostyly is what might crystallise some of such distinguishing properties and also maintains vegetative differences in the equilibrium dictated by circumstances, sometimes in coordination with homostyly.

In Primula, Linum and Lythrum the morphs exhibit no outwardly detectable differences in style length prior to the free-spore period. However, as mentioned, precocious pollen size dimorphism betrays an earlier differential growth. Further, as revealed by Linskens (1964) for Petunia, a growth principle produced in the anthers is apparently responsible for the normal elongation of the style. It is possible that in heterostyly the initial control of growth by a hormone present in the differentiating floral apex is at a certain stage taken over or completed by a factor accumulating or originating in the anthers. If this interpretation is correct, it may be further surmised that the growth-inducing or repressing factor in the anther is closely related to the number and frequency of cell divisions in the anther primordium, as expressed by pollen and anther size dimorphism. A low rate of divisions results in large gains, and is associated with induction of cell elongation in stamen filaments and its repression in styles of thrum flowers; a high rate of divisions results in the reverse condition in pin flowers.

The significance of the association of pollen size heteromorphism with heterostyly could thus be summed up as follows: resulting from a distinguishing control of growth rate in the morphs, it becomes itself involved in, or generates, a differential growth-controlling agent. It conditions the grains-and consequently the tubes as well-for chemical and structural specificities involved in recognition. Finally, it may perhaps furnish an appropriate number of grains to be deposited on stigmas of the morphs, according to their positions and to the demands of the pollination process.

Neither the morphological nor the physiological components of heteromorphic incompatibility are subordinate; instead, each is the outcome of the other. The refinement in heterostyly which eluded us is the potentiality of one and the same mechanism to fulfil a double function: the faculty of regulating the pollen loads on the stigmas, but mainly and perhaps primarily the function of controlling their subsequent fate. 


\section{REFERENCES}

BAKER, H. G. 1964. Variation in style length in relation to outbreeding in Mirabilis (Nyctaginaceae). Evolution, 18, 507-509.

BAKER, H. G. 1966. The evolution, functioning and breakdown of heteromorphic imcompatibility systems. I. The Plumbaginaceae. Evolution, 20, 349-368.

BRÄM, M. 1943. Untersuchungen zur Phänanalyse und Entwicklungsgeschichte der Blüten von Primula pulverulenta, P. Cockburniana und ihrer $\mathrm{F}_{1}$-Bastarde. Arch. Julius Klaus-Stift. Vererb Forsch., 18, 235-259.

BREWBAKER, J. L. 1957. Pollen cytology and self-incompatibility systems in plants. $\mathcal{F}$. Hered., 48, 271-277.

Gleland, R. 1971. Cell wall extension. A. Rev. Pl. Phys., 22, 197-222.

DARWIn, C. 1877. The Different Forms of Flowers on Plants of the Same Species. Murray, London. DAHLGREN, x. v. o. 1916. Zytologische und embryologische Studien über die Reihen Primulales und Plumbaginales. K. svenska Vetensk-Akad. Handl., 56, 1-80.

DICKINSON, H. G., AND LEWIS, D. 1973. Cytochemical and ultrastructural differences between intraspecific compatible and incompatible pollinations in Raphanus. Proc. R. Soc. Lond., $B, 183,21-38$.

DOWRICK, v. P.J. 1956. Heterostyly and homostyly in Primula obconica. Heredity, 10, 219-236.

DULBerger, R. 1970. Tristyly in Lythrum junceum. New Phytol., 69, 751-759.

DULBERGER, R. 1974. Structural dimorphism of stigmatic papillae in distylous Linum species. Am. J. Bot., 61, 238-243.

DULBERGER, R. 1975. Intermorph structural differences between stigmatic papillae and pollen grains in relation to incompatibility in Plumbaginaceae. Proc. $R$. Soc. Lond., $B$, 188, 257-274.

ERNST, A. 1932. Zur Kenntnis der Heterostylie bei tropischen Rubiaceae. Arch. Julius Klaus-Stift. Vererb Forsch., 7, 241-280.

ERNST, A. 1933. Weitere Untersuchungen zur Phänanalyse, zum Fertilitätsproblem und zur Genetik heterostyler Primeln. 1. Primula viscosa All. Arch. Julius Klaus-Stift. Vererb Forsch., 8, 1-215.

ESSER, x. 1953. Genomverdopplung und Pollenschlauchwachstum bei Heterostylen. $Z$. indukt. Abstamm.-u. Vererb Lehre, 85, 28-51.

GANDERS, F. R. 1974. Disassortative pollination in the distylous plant fepsonia heterandra. Can. J. Bot., 52, 2401-2406.

hetTZ, B., JEAN, R., AND PRENSier, G. 1971. Observation de la surface du stigmate et des grains de pollen de Linum austriacum hétérostyle. C. R. Hebd. Séanc. Acad. Sci., Paris, 273, 2493-2495.

HESLOP-HARRISON, J. 1957. The experimental modification of sex expression in flowering plants. Biol. Rev., 32, 38-91.

HESLOP-HARRISON, J. 1968. Ribosome sites and S gene action. Nature, Lond., 218, 90-91. HESLOP-HARRISON, J. 1971. The pollen wall: structure and development. In Pollen, Development and Physiology (ed. J. Heslop-Harrison), pp. 75-98. Butterworths, London. HESLOP-HARRISON, J., AND HESLOP-HARRISON, Y. 1958. Long-day and auxin induced male sterility in Silene pendula L. Port. Acta biol., 5, 79-94.

HESLOP-HARRISON, J., HESLOP-HARRISON, Y., KNOX, R. B., AND hOWLETT, B. J. 1973. Pollenwall proteins: "gametophytic" and "sporophytic" fraction in the pollen wall of the Malvaceae. Ann. Bot., 37, 403-412.

HESLOP-HARRISON, J., KNOX, R. B., AND HESLOP-HARRISON, Y. 1974. Pollen-wall proteins: exine-held fractions associated with the incompatibility response in Cruciferae. Theoret. appl. Genet., 44, 133-137.

HOWLETT, B. J., KNOX, R. B., AND HESLOP-HARRISON, J. 1973. Pollen-wall proteins: release of the allergen Antigen $\mathbf{E}$ from intine and exine sites in pollen grains of ragweed and Cosmos. 7. Cell. Sci., 13, 603-619.

Jost, L. 1907. Ủber die Selbststerilität einiger Blüten. Bot. Ztg., 65, 77-117.

KöHLER, E. 1973. Über einen bemerkenswerten Pollendimorphismus in der Gattung Waltheria L. Grana, 13, 57-64.

LAIBACH, F. 1930. Entwicklungsphysiologische Unterschiede zwischen Lang- und Kurzgriffeln bei einer heterostylen Pflanze (Linum austriacum L.). Z. indukt. Abstamm.-u. Vererb Lehre, 55, 157-184.

LAMPORT, D. T. A. 1970. Cell wall metabolism. A. Rev. Pl. Physiol., 21, 235-270.

LEVIN, D. A. 1968. The breeding system of Lithospermum caroliniense : adaptation and counteradaptation. Am. Nat., 102, 427-441. 
LEWIS, D. 1942. The physiology of incompatibility in plants. I. The effect of temperature. Proc. R. Soc. Lond., B, 131, 13-26.

LEWIS, D. 1943. The physiology of incompatibility in plants. II. Linum grandiflorum. Ann. Bot., 7, 115-117.

LEWIS, D. 1954. Comparative incompatibility in angiosperms and fungi. Adv. Genet., 6, 235-285. Academic Press, New York.

LEWIS, D., AND RAO, A. N. 1971. Evolution of dimorphism and population polymorphism in Pemphis acidula Forst. Proc. R. Soc. Lond., B, 178, 79-94.

LINSKENS, H. F. 1964. The influence of castration on pollen tube growth after self-pollination. In Pollen Physiology and Fertilization. (Ed. H. F. Linskens), pp. 230-236. North-Holland Publ., Amsterdam.

MATHER, K., AND DE WINTON, D. 1941. Adaptation and counter-adaptation of the breeding system in Primula. Ann. Bot., 5, 297-311.

MATtSON, D., KNOX, R. B., heslop-HARRISON, J., AND hesLop-harrison, y. 1974. Protein pellicle of stigmatic papillae as a probable recognition site in incompatibility reactions. Nature, Lond., 247, 298-300.

MULCAHY, D. L., AND CAPORELlO, D. 1970. Pollen flow within a tristylous species: Lythrum salicaria. Am. F. Bot., 57, 1027-1030.

ORNDUFF, R. 1966. The origin of dioecism from heterostyly in Nymphoides (Menyanthaceae). Evolution, 20, 309-314.

ORNDUFF, R. 1970. Incompatibility and the pollen economy in Fepsonia parryi. Am. F. Bot., 57, 1036-1041.

ORNDUFF, R. 1971. The reproductive system of Fepsonia heterandra. Evolution, 25, 300-311.

PANDEY, K. K. 1960. Evolution of gametophytic and sporophytic systems of self-incompatibility in angiosperms. Evolution, 14, 98-115.

PANDEY, K. K. 1970. Time and site of S-gene action, breeding systems and relationships in incompatibility. Euphytica, 19, 364-372.

schaeppi, H. 1935. Zur Kenntnis der Heterostylie von Gregoria Vitaliana Derby. Ber. schweiz. bot. Ges., 44, 109-132.

sCHосн-воDMRR, н. 1934. Zum Heterostylieproblem: Griffelbeschaffenheit und Pollenschlauchwachstum bei Fagopyrum esculentum. Planta, 22, 149-152.

UBISCH, G. vON. 1925. Genetisch-physiologische Analyse der Heterostylie. Biblphia genet., $2,287-342$.

vUILLEUMier, B. s. 1967. The origin and evolutionary development of heterostyly in angiosperms. Evolution, 21, 210-226. 